\title{
Fundamentals of Philosophy
}

\section{ERROL E. HARRIS}

Valuable as both a foundation and a conspectus, this book acquaints the reader with works of some of the most important philosophers and outlines major problems and discussions which have formed the basis of philosophy.

\section{Non-Linguistic Philosophy}

\section{A. C. EWING}

Challenges the positivist school of philosophy: attacking their views and arguments and trying to create a philosophy which goes beyond the limits set by them.

Muirhead Library of Philosophy

\section{Belief}

\section{H. H. PRICE}

Based on the Gifford Lectures delivered at the University of Aberdeen in 1959-60, this volume includes a discussion of the relation between belief and knowledge and of the various sorts of evidence we have for our beliefs, including the evidence of testimony; it considers the traditional 'occurrence analysis', the modern 'dispositional analysis', moral and religious beliefs and concludes with a discussion of the Theistic religious outlook.

Muirhead Library of Philosophy

\section{Bertrand Russell's Theory of Knowledge}

\section{ELIZABETH RAMSDEN EAMES}

A comprehensive treatment of Russell's epistemology, beginning with his earliest views and drawing attention to features of his more recent work.

\section{Introduction to Logic}

\section{The Criticism of Arguments}

\section{PETER ALEXANDER}

'... comes like a breath of fresh air. . . . a comprehensive introduction to this subject which is not only clear and well-blanced but also stimulating.' Contemporary Review.

Paperback 30s Cloth 60s

\section{Christian and Hindu Ethics}

\section{S. C. THAKUR}

The first systematic and detailed work which attempts to bring out both the differences and similarities of Christian and Hindu ethics.

\section{Allen \& Unwin}




\section{The John Hopkins Press Ltd}

\section{VOX POPULI}

\section{By George Boas}

Tracing the meaning of the proverb "Vox Populi, vox Del," through history, the author finds that the People are not an easily identifiable group. In seven essays he attempts to determine who the People were and how writers and thinkers have regarded them. October $336 \mathrm{pp}$

$86 \mathrm{~s}$ net paper $27 s$ net

\section{COVENANT: THE HISTORY OF A BIBLICAL IDEA}

\section{By Delbert R. Hillers}

This book makes available and comprehensive to the layman the insights and interpretations that have lately clarified much of the history and meaning of the idea of covenant. Through analysis of the style, content and language of biblical and extra-biblical documents, the author renders an unusually complex idea understandable.

September

208pp

67 s net paper 19 s net

\section{IDEAS ABOUT SUBSTANCE}

\section{By Albert L. Hammond}

The author enters the ancient battle with a unique personal document that ranges from Thales ideas of substance through Phenomenalism. He presents the history of an idea, but he also conveys a deep sense of the world's reality in living things. September

$172 \mathrm{pp}$

$57 \mathrm{~s}$ net paper 19s net

\section{THE LEGACY OF LOGICAL POSITIVISM}

\section{Studies in the Philosophy of Science}

\section{Edited by Peter Achinstein and Stephen F. Barker}

The impact of logical positivism has been felt in various fields, but above all in the philosophy of science, a discipline which the logical positivists made particularly their own. This book examines the movement and its influence on modern views of the nature of Science.

October

320pp

81 s net

\section{PHENOMENOLOGY OF MORAL EXPERIENCE}

\section{By Maurice Mandelbaum}

The author attempts to show the necessity for grounding any ethical theory upon the phenomenological analysis of moral experience. In six essays he probes the nature of that experience and of the moral controversies to which it gives rise.

December

$344 \mathrm{pp}$

paper 24s net

\section{GIAMBATTISTA VICO :}

\section{AN INTERNATIONAL SYMPOSIUM}

Edited by Giorgio Tagliacozzo

"Vico" writes Sir Herbert Read in this volume, "is probably the most unacknowledged source of ideas in the history of philosophy". Yet, few thinkers have exerted so pervasive an influence on Western ideas. This volume of original essays marks the tercentenary of the birth of Giambattista Vico and documents his influence on modern thought.

November

$608 \mathrm{pp}$

114 s net 


\section{The Logic of Leviathan}

\section{The Moral and Political Theory of Thomas Hobbes}

\section{David P. Gauthier}

This book presents a reading of Hobbes's moral and political theories which is faithful to the text and of great current philosophical interest. The author shows how Hobbes's psychology subverts his conceptual foundations for secular and rational morality and for a political community, and suggests the relevance of a study of Hobbes to such general problems as the relation of morality and prudence. $38 s$ net

\section{Essays in Greek Philosophy}

\section{RICHARD ROBINSON}

These papers, originally published in journals between 1936 and 1956, are now reprinted as a book, substantially in their original form, except for the last-on Aristotle's doctrine of incontinence which is translated from the French.

Five of the essays are about Plato, and one is on analysis in Greek grometry. 30s net

\section{The Landscape of the Mind}

\section{Pastoralism and Platonic Theory in Tasso's AMINTA and Shakespeare's} Early Comedies

\section{RICHARD CODY}

What should we think of the shepherd's life, asks Thoreau, 'if his flocks always wandered to higher pastures than his thoughts'? This essay considers how one should think of the shepherd's life in certain Renaissance plays and poems as philosophic, and why. 40 s net

\section{Coleridge and the Pantheist Tradition}

\section{THOMAS MCFARLAND}

Coleridge sought throughout his career to separate his own views from panthcism, but was strongly attracted to it nonetheless. This book assesses his intellectual position in terms of this dilemma, which is reflected in all his work. 70s net

\section{Languages of Art}

\section{An Approach to a Theory of Symbols}

\section{NeLSON GOODMAN}

This book is about symbol systems : the way in which reality is represented in the arts. The major types of symbols and symbol systems are examined and compared, from those of natural language to those of pictorial representation and of musical notation. Problems in the theory of knowledge are encountered, and questions of pattern recognition, concept formation, perception, and induction are discussed. 42 s net

\section{The Bhagavad Gitā}

\section{Translated, with a Commentary based on the Original Sources by}

R. C. ZAEHNER

Of the Hindu sacred books the Bhagavad $\mathrm{G}_{\mathbf{i}} \mathrm{ta}^{-}$is the most widely read and probably the most important for the understanding of religious mysticism. This edition tries to explain its thought from the Gitā itself and closely allied texts--the later verse Upanishads and the doctrinal portions of the Mahābhārata. 88s net 


\section{The University of Chicago Press}

\section{Selected Letters of Friedrich Nietzsche}

\section{Edited and Translated by Christopher Middleton}

Traditionally cast in the popular mind as the ultimate anti-Semitic German nationalist, Nietzsche has been misrepresented, misinterpreted and misused for decades. Christopher Middleton has assembled a selection of letters which, as a whole, gives a sympathetic portrayal of a much maligned personality. The letters, says Mr. Middleton, "are like aerial photography of a subterranean labyrinth". This selection reveals a ground-plan of that labyrinth.

$72 \mathrm{~s}$.

The Basic Writings of Josiah Royce in two volumes

Edited and with an Introduction by John J. McDermott

This two-volume edition of selections from the complete range of Royce's work has a threefold purpose. First, it illustrates the scope and quality of his thought. Second, it is a detailed presentation of the viable relationship Royce forged between the local experience of community and the demands of a philosophical and scientific vision of the entire human situation. Finally, it demonstrates the relevance of Royce's judgement in cultural, moral and religious matters.

2 vols., $135 s$.

\section{Plato's Analytic Method}

Kenneth M. Sayre

Applying the analytical methods of modern logic to problems of interpretation in Plato, Kenneth Sayre traces the development of Plato's analytic method from the crude form expressed in the Phaedo to the considerably more sophisticated and powerful techniques practiced in the later methodological dialogues. His study offers some highly original insights that are sure to stimulate new thinking among Plato scholars, classicists and analytical philosophers in general.

$88 \mathrm{~s}$.

The University of Chicago Press 126 Buckingham Palace Road London SW1

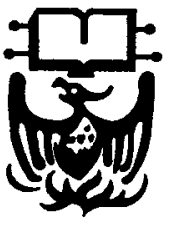




\section{RATIO}

edited by STEPHAN KÖRNER

\begin{tabular}{lll}
\hline Volume XI & DECEMBER 1969 & No. 2 \\
\hline
\end{tabular}

Carlo Giannoni

E. D. KLEMKE

J. K. Mish'alani

M. S. Gram

W. SACKSTEDER

MARGARET A. BODEN

W. H. WALSH

C. J. F. WILliams

P. GEACH

Mary Hasse
A Defense of Logical Conventionalism

The Argument from Design

Rule and Exception in Morals

The Reality of Time

Presentational Arguments

Miracles and Scientific Explanation

Kant's Analytic (Jonathan Bennett)

Past, Present and Future and Papers on

Time and Tense (Arthur Prior)

Bertrand Russell and the British Tradition in Philosophy (D. F. Pears)

The Foundations of Scientific Inference (Wesley C. Salmon)

BASIL BLACKWELL

Broad Street, Oxford

Price: 20s. net

Annual Subscription 36s. net

\section{Induction and Intuition in Scientific Thought}

P. B. Medawar

'Why are most scientists completely indifferent to-even contemptuous ofscientific methodology? . . I I thought it important to explain what is wrong with the traditional methodology of 'inductive' reasoning .... and to show that the alternative scheme of reasoning associated with the names of Whewell and Pierce and Popper can give the scientist a certain limited but useful insight into the way he thinks.' Preface.

'Sir Peter is highly persuasive and his philosophy clearly gives more scope to imaginative thinking.' The Sunday Times. hardback 16s University Paperback $7 s$ Methuen

\section{Back lssues of Journals} in

\section{THE HUMANITIES AND SCIENCES}

alwaye required by

Wm. DAWSON a SONS LTD.

Back lasues Dopartment

Cannon House

Folkestone, Kent England

Telephone: Folkestone 57421

Cables : Dawbooks Folkestone 


\section{Kierkegaard's Concluding Unscientific Postscript}

Translated from the Danish by DAVID F. SWENSON

Introduction and Notes by WALTER LOWRIE

119.s net paper covers 35s net Princeton University Press

\section{Set Theory and Its Logic}

Willard VAN ORMAN QUINE

This is an introduction to abstract set theory and to various axiomatic systematizations of the subject. Previous books by the author include Mathematical Logic, Methods of Logic, From a Logical Point of View, and Word and Object. Second edition $75 s$ net Harvard University Press

\section{The Philosophy of the Enlightenment}

\section{ERNST CASSIRER}

Translated by Fritz C. A. Koelln and James P. Pettegrove This is a translation of Die Philosophie der Aufklärung, the German edition of which was published in 1932. 80s net paper covers 26s net Princeton University Press

\section{Chao Lun}

\section{The Treatise of Seng-Chao}

A Translation with Introduction, Notes and Appendices by

W ALTER LIEBENTHAL

This work is the main scripture of the first period of Chinese Buddhism (A.D. 300-700) before Dhyana-Buddhism absorbed all other interests. The author believes that the two periods are connected and that in Dhyana-Buddhism the earlier thinking emerged, cleansed from the traces of its Indian origin. Seng-chao interpreted Mahayana, Hui-neng and Shen-hui rethought it. Second edition 88 s net Hong Kong University Press

\section{St. Augustine's Early Theory of Man, A.D. 386-391}

ROBERT J. O'CONNELL

During the period between his conversion and his ordination to the priesthood, Augustine developed a theory of man and a perception of Christianity that influenced all his early works. In Plotinus' Enneads he discovered the most comprehensive framework for his concept of man as a 'fallen soul'. Father O'Connell approaches Augustine through Plotinus in order to demonstrate that the Plotinian frame furnishes the matrix for the elements of Christianity which Augustine was trying to understand. $95 \mathrm{~s}$ net Harvard University Press

\section{St. Augustine's Confessions: The Odyssey of Soul}

\section{ROBERT J. O'CONNELL}

The author examines the Confessions in the light of the theory established in St. Augustine's Theory of Man. $63 \mathrm{~s}$ net Harvard University Press 


\section{MIND}

A Quarterly Review of Psychology and Philowophy

Edited by: Prof. GILBERT RYLE

\section{OCTOBER, 1969}

1 The Possibly-true and the Possible: A. N. PRIOR

II Seeing and Observing: RUTH A. PUTNAM

III Truth and Sentences: RITA NOLAN

IV The Privacy of Experience: T. L. S. SPRIGGE

V A Conceptual Investigation of Witkin's Notion of Perceptual Style: R. M. KURTZ

VI The Practicality of Moral Reasoning: M. F. COHEN

VIl Is Immediate Knowledge Reason Based? CHARLES PAILTHORP

VIII Discussions:

Tactile and Non-tactile Awareness: DIOGENES ALLEN

Professor Zink on "The Meaning of Proper Names": MICHAEL DURRANT

Oldenquist on Rules and Consequences: J. E. ATWELI

Imagination and Confirmation: GILBERT WALTON

Can a Determinist Deliberate? CHAUNCEY DOWNES

Former Persons: ASTRID KJAERGAARD

A Note on Mr. Demos' Note on Plato on Moral Principles: F. B. GRAHAM

Another Ethical Paradox: C. R. KORDIG

Watkins and the Taylor-Warrender Thesis: COLWYN WILLIAMSON

Quine's Indeterminacy Thesis: R. KIRK

IX Critical Notices:

M. R. Ayers, The Refutation of Determinism: An Essay in Philosophical Logic: J. W. YOLTON

R. J. Fogelin, Evidence and Meaning J. O. URMSON

$\mathrm{X}$ New Books

XI Notes

Published for the MIND ASSOCIATION by

BASLL BLACKWELL, 49 Broad Street, Oxfond

\section{Politics and Experience}

\section{Essays presented to Michael Oakeshott}

Edited by PRESTON KING and B. C. PAREKH

These thirteen essays on philosophy, history and politics have been specially written to mark the retirement of Professor Michael Oakeshott from the Chair of Political Science at the London School of Economics and Political Science.

\section{CAMBRIDGE} UNIVERSITY

\section{PRESS}

\section{The Christian Knowledge of God}

\section{H. P. OWE N}

The aim of this book is to discuss as rigorously as possible the Christian claim to know God as a transcendent and personal reality. The underlying thesis is that although God's existence cannot be logically demonstrated it can be known by spiritual intuition, and $\mathrm{Mr}$ Owen seeks to show that this intuition and the various forms of spiritual experience it generates are entirely reasonable. 485111071

\section{The Athlone Press} UNIVERSITY OF LONDON 
Recent Publications in SYNTHESE LIBRARY

\section{Philosophical Logic}

edited by

J. W. DAVIS, D. J. HOCKNEY

and W. K. WILSON

The University of Western Ontario

1969, VIII +277 pp., Dfl. 45.-

\section{Words and Objections}

Essays on the Work of W. V. Quine

edited by

DONALD DAVIDSON

Princeton University and

JAAKKO HINTIKKA

University of Helsinki and Stanford University

1969, VII + 366 pp., Dfl. 48. -

\section{Boston Studies in the} Philosophy of Science

\section{VOLUME IV}

Proceedings of the Boston Colloquium for the Philosophy of Science 1966/1968

edited by

ROBERT S. COHEN and

MARX W. WARTOFSKY

Boston University

1969 , VIII + 537 pp., Dfl. 69.-

\section{Boston Studies in the Philosophy of Science \\ VOLUME $\mathbf{V}$}

Proceedings of the Boston Colloquium for the Philosophy of Science 1966/1968

edited by

ROBERT S. COHEN and

MARX W. WARTOFSKY

Boston University

1969, VIII + 482 pp., Dfl. 58. -

\section{Reidel}

\section{Publishing Company}

\section{DORDRECHT-HOLLAND}

\section{THE ART OF GONVERSATION}

Many people suffer from loneliness simply because they are unable to express themselves as they would wish. These people are missing things in life. Happiness and success go hand in hand with the ability to make good conversation.

Send now for particulars of this and 20 other tapes on self-improvement. They include:Vita-Dynamics.

Public Speaking.

Mind Management.

Trance Deopening.

Confidonce Course.

Publications:-

Sleop-learning: Its Theory and Technique.

Mental Power through Sleep-suggestion.

Distributors of the Cassotto battery/main Sleep-o-matic Unit. Pillow spoakers. Time Clocks, and the new amazing whispering pillow.

$$
\text { Brochures from }
$$

EDUCATIONAL RECORDINGS LTD.

21 Bishops Glose, London, E.17

THE BRITISH JOURNAL OF AESTHETICS

A Journal for the underotandins of the principles of criticiem and apprecintion

Editor: HAROLD OSBORNE

Vol. 9 No. 4

October 1969

\section{CONTENTS}

Apology for Aesthetics

RUth SAW

Appreciation considered as a Skill

$$
\text { Harold OsBorne }
$$

The Aesthetic Experience

R. F. RACY

Heidegger's Philosophy of Art S. L. BARTKY

Indian Aesthetics and the Nature of

the Dramatic Emotions

Sucharita Gamlath

The Personal Heresy in Criticism

Book Reviews ROBERT D. HUME

Publushed Quarterly for the British Society of Aesthetics by Thomas \& Hudson, Lid., 30 Bloomsbury St., W.C.1. Price 63 per anium (single issues is/6 fiom the publishers or through any bookseller. The Journal is supplied through any bookseller. The Journal is supplied two gulneas per annum. Forms of subseription from the Hon. Secretary, clo Department of Phllosophy, Bedford College, Regents Park. London, N.W.1 